\title{
NOTA/NOTE
}

\section{Aporte de las Áreas Marinas Protegidas del Sistema de Parques Nacionales Naturales a la representatividad de ecosistemas en Colombia}

\section{Contribution of the Marine Protected Areas of the National Natural Park System to the ecosystems representativeness of Colombia}

\author{
David Alonso C.* e Ivonne Corredor-Rubiano \\ $\begin{array}{ll}\text { (iD) } 0000-0002-1461-3401 & \text { (iD } 0000-0002-3404-5261\end{array}$ \\ 1. Instituto de Investigaciones Marinas y Costeras (Invemar), Santa Marta, Colombia.david.alonso@invemar.org.co,ivocorredor@gmail.com \\ * Autor de correspondencia.
}

\section{RESUMEN}

$\mathrm{S}$ e llevó a cabo un análisis de representatividad de ecosistemas marinos y costeros en las 18 Áreas Marinas Protegidas (AMP) administradas por el Sistema de Parques Nacionales Naturales de Colombia (SPNN) y sus cambios a 2020 con respecto a 2010. Para el Caribe, aumentó la representatividad de manglares, pastos marinos, fondos sedimentarios y playones salinos, mientras para el Pacífico, aumentó la representatividad de estuarios, fondos sedimentarios, manglares, planos intermareales de lodo, playas arenosas y montañas submarinas. Se incluyeron los corales de profundidad como un nuevo ecosistema para el SPNN. A partir de clases de representatividad determinados para este análisis, se encontró que el único ecosistema sin representatividad (0\%) (corales de profundidad) pasó a ser sobrerrepresentado ( $\geq 60 \%$ ). El número de ecosistemas en representatividad baja disminuyó de 8 a $7(<10 \%)$ mientras los ecosistemas en representatividad media aumentaron de 9 a 10 (10-29\%). En la última década, ecosistemas de importancia ecológica como los estuarios $(0,55 \%)$ en el Caribe y los bosques mixtos de guandal $(0,22 \%)$ para el Pacífico no presentaron ningún cambio en su representatividad. Se evidencia la necesidad de incrementar la investigación y conocimiento de los hábitats bentónicos profundos para incluirlos dentro del sistema, y aprovechar el escenario de diálogo internacional para contribuir y comprometerse con metas ambiciosas de conservación en marco pos-2020 del Convenio de Diversidad Biológica.

PALABRAS CLAVE: vacíos de representatividad, conservación marina, planificación de la conservación, meta Aichi 11, Convenio de Diversidad Biológica

\section{ABSTRACT}

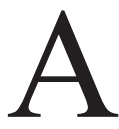
$\mathrm{n}$ analysis of representativeness of marine and coastal ecosystems was carried out in the 18 Marine Protected Areas (MPAs) administered by the System of National Natural Parks of Colombia (SPNN) and their changes in 2020 compared to 2010. The Caribbean increased the representativeness of mangroves, seagrasses, sedimentary bottoms, and saline beaches. In the Pacific, estuaries representativeness, sedimentary bottoms, mangroves, intertidal mudflats, sandy beaches, and seamounts increased. Deep-sea corals were included as a new ecosystem for the SPNN. From the representativeness ranges determined for this analysis, it was found that the only ecosystem with no representativeness $(0 \%$ ) (Deep-sea corals) became overrepresented ( $\geq 60 \%)$. The number of low representative ecosystems decreased from 8 to $7(<10 \%)$, while the medium representative ecosystems increased from 9 to $10(10-29 \%)$. In the last decade, ecosystems of ecological importance such as estuaries $(0.55 \%)$ in the Caribbean and mixed guandal forests $(0.22 \%)$ for the Pacific did not change their representativeness. There is evidence of the need to increase research and knowledge of deep benthic habitats to include them within the System and take advantage of the international dialogue scenario to contribute to ambitious conservation goals within the post-2020 framework of the Convention on Biological Diversity.

KEY WORDS: representativeness gaps, marine conservation, conservation planning, Aichi target 11, Convention of Biological Diversity 
Con el fin de reducir significativamente el ritmo actual de pérdida de la diversidad biológica, la Conferencia de las Partes del Convenio de Diversidad Biológica (CDB) propuso en 2010 el Plan Estratégico para la Diversidad Biológica 2011-2020, denominado Metas Aichi, estableciendo como Meta 11 alcanzar, con áreas protegidas y otras medidas eficaces basadas en áreas, una superficie de $17 \%$ de las aguas terrestres y continentales y $10 \%$ de las áreas costeras y marinas, a través de sistemas gestionados de manera efectiva y equitativa, ecológicamente representativos y bien conectados, e integrados en paisajes terrestres y marinos más amplios (CBD, 2010).

La representatividad ecológica de un sistema de áreas protegidas está dada si existe una muestra adecuada de biodiversidad a diferentes niveles de organización biológica (genes, especies, comunidades y ecosistemas), que garanticen los procesos ecológicos y su viabilidad a largo plazo (Stevens, 2002; Dudley and Parish, 2006; Barr et al., 2011). La representatividad se reconoce como un atributo clave para la planificación de la conservación (Margules and Pressey, 2000). Aunque no hay un consenso sobre cuál debe ser el porcentaje que cada elemento de biodiversidad marina debe estar representado dentro de un sistema, existe evidencia científica con diversos modelos y estudios empíricos que sugiere que debería garantizarse entre $20 \%$ y $50 \%$ de cada ecosistema o hábitat para cumplir múltiples objetivos de conservación en las Áreas Marinas Protegidas (AMP) (Sala et al., 2002; Aírame et al., 2003; Gell y Roberts, 2003; Gaines et al., 2010; O'Leary et al., 2016).

Colombia tiene un Sistema Nacional de Áreas Protegidas (SINAP) con 35 AMP que hacen parte del Subsistema de AMP (SAMP). Este subsistema, contiene 17 AMP de gestión regional, administradas por las Corporaciones Autónomas Regionales y/o de Desarrollo Sostenible del Caribe y Pacífico colombiano. Así mismo, cuenta con 16 AMP del Sistema de Parques Nacionales Naturales (SPNN), el cual es el conjunto de áreas con valores excepcionales para el patrimonio nacional que, debido a sus características naturales, culturales o históricas, se reservan y declaran en cualquiera de las categorías existentes (Decreto 2811, 1974). En la actualidad, las AMP del SPNN se distribuyen en tres categorías de manejo: 1) Parque Nacional Natural (PNN); 2) Vía Parque (VP); y 3) Santuario de Fauna y/o Flora (SFF). Adicionalmente, existen dos Distritos Nacionales
In 2010, the Conference of the Parties to the Convention on Biological Diversity (CBD) proposed the Strategic Plan for Biological Diversity 2011-2020 to significantly reduce the current rate of loss of biological diversity, called Aichi Targets. This Plan, established as Target 11, achieve with protected areas and other effective area-based measures an area $17 \%$ of terrestrial and continental waters, and $10 \%$ of coastal and marine areas; the areas should be systems managed effectively and equitably, ecologically representative and well- connected, and integrated into broader landscapes and seascapes (CBD, 2010).

The ecological representativeness of a system of protected areas is given if there is an adequate sample of biodiversity at different levels of biological organization (genes, species, communities, and ecosystems), which guarantees ecological processes and their long-term viability (Stevens, 2002; Dudley and Parish, 2006; Barr et al., 2011). The representativeness is recognized as a key attribute for conservation planning (Margules and Pressey, 2000). Although there is no consensus on what percentage each element of marine biodiversity should be represented within a system, scientific evidence from different models and empirical studies suggests that between $20 \%$ and $50 \%$ of each ecosystem or habitat should be guaranteed to meet multiple objectives for the conservation of MPA (Sala et al., 2002; Aírame et al., 2003; Gell and Roberts, 2003; Gaines et al., 2010; O'Leary et al., 2016).

Colombia has a National System of Protected Areas (SINAP, in its Spanish acronym) with 35 Marine Protected Areas (MPAs) that are part of the MPA Subsystem (SAMP). This subsystem contains 17 sub-national MPAs, administered by subnational environmental authorities of the Caribbean and the Colombian Pacific. Likewise, it has 16 MPAs of the System of National Natural Parks (SPNN, in its Spanish acronym), which is the set of areas with exceptional values for the national heritage that, due to their natural, cultural, or historical characteristics, are reserved and designated in any of the existing categories (Decree 2811, 1974), and administered by National Natural Parks of Colombia (PNNC, in its Spanish acronym). Currently, the MPAs of the SPNN is divided into three management categories: 1) National Natural Park (NNP), 2) Via Park (VP), and 3) Sanctuary of Fauna and Flora (SFF). Besides, two National District of Integrated Management (NDIM) are not part of the SPNN. However, the delegation of the Ministry of Environment and Sustainable Development 
de Manejo Integrado (DNMI) que no son parte del SPNN pero que, por delegación del Ministerio de Ambiente y Desarrollo Sostenible (MADS), son administrados por Parques Nacionales Naturales de Colombia (PNNC) y que para el presente estudio se incluyen dentro del sistema, dado el esfuerzo en la planificación y gestión que realiza PNNC.

En 2010 se realizó un análisis de vacíos de representatividad ecológica a nivel de ecosistemas marinos y costeros para 13 áreas del SPNN (Segura-Quintero et al., 2012). El objetivo de este estudio fue evaluar, una década después, los avances y la contribución de las AMP administradas por PNNC (Tabla 1), a la representatividad del SAMP y a la meta 11 de Aichi, con el fin de sugerir futuros esfuerzos de conservación de país y aportar en la discusión de la construcción de las nuevas metas para Colombia en el marco de CDB pos-2020.

Tabla 1. Áreas marinas protegidas administradas por Parques Nacionales Naturales Colombia con sus correspondientes categorías de manejo y equivalencia con las categorías de la Unión Internacional para la Conservación de la Naturaleza (UICN). PNN: Parque Nacional Natural. VP: Vía Parque. SFF: Santuario de Fauna y/o Flora. DNMI: Distrito Nacional de Manejo Integrado. Las áreas de cobertura corresponden a los valores oficiales designados en el acto administrativo (resolución de declaratoria).
(MADS, in its Spanish acronym) is administered by PNNC. This study includes the two NDIM within the SPNN, given the planning and management effort carried out by the PNNC.

In 2010, an analysis of ecological representativeness gaps was carried out at the marine and coastal ecosystems for 13 areas of the SPNN (SeguraQuintero et al., 2012). The objective of this study is to evaluate a decade later the progress and contribution made by the MPAs managed by PNNC (Table 1), to the representativeness of the SAMP and Aichi Target 11, within order to suggest future conservation efforts of the country and contribute to the discussion of the construction of the new goals for Colombia in the post-2020 CBD framework.

Five of the evaluated MPAs do not have marine coverage (SFF Los Flamencos, NNP Sierra Nevada de

Table 1. Marine protected areas managed by National Natural Parks of Colombia with their corresponding management categories and equivalence with the categories of the International Union for Conservation of Nature (IUCN). NNP: National Natural Park. VP: Via Park. SFF: Sanctuary of Fauna and/or Flora. NDIM: National District of Integrated Management. The coverage areas correspond to the official values designated in the administrative Act (Designation Resolution).

\begin{tabular}{|c|c|c|c|c|c|c|c|}
\hline $\mathbf{N} .^{\circ}$ & $\begin{array}{l}\text { Año de } \\
\text { creación/ } \\
\text { Creation } \\
\text { year }\end{array}$ & Nombre/Name & $\begin{array}{l}\text { Categoría } \\
\text { UICN/ } \\
\text { IUCN } \\
\text { Category }\end{array}$ & $\begin{array}{l}\text { Región/ } \\
\text { Region }\end{array}$ & $\begin{array}{l}\text { Área de cobertura } \\
\text { terrestre/Land } \\
\text { coverage área } \\
\text { (ha) }\end{array}$ & $\begin{array}{c}\text { Área de cobertura } \\
\text { marina/Marine } \\
\text { coverage area } \\
\text { (ha) }\end{array}$ & $\begin{array}{l}\text { Área de cobertura } \\
\text { total/Total coverage } \\
\text { area } \\
\text { (ha) }\end{array}$ \\
\hline 1 & 1964 & $\begin{array}{c}\text { PNN/NNP Sierra Nevada } \\
\text { de Santa Marta }\end{array}$ & II & \multirow{6}{*}{$\begin{array}{l}\text { Caribe continental/ } \\
\text { Continental Caribbean }\end{array}$} & 383000 & 0 & 383000 \\
\hline 2 & 1969 & PNN/NNP Tayrona & II & & 8056 & 6943 & 15000 \\
\hline 3 & 1969 & VP Isla de Salamanca & III & & 27315 & 28884 & 56200 \\
\hline 4 & 1977 & SFF Los Flamencos & $\mathrm{Ib}$ & & 7000 & 0 & 7000 \\
\hline 5 & 1977 & $\begin{array}{c}\text { SFF Ciénaga Grande de } \\
\text { Santa Marta }\end{array}$ & $\mathrm{Ib}$ & & 26810 & 0 & 26810 \\
\hline 6 & 1977 & $\begin{array}{l}\text { PNN/NNP Corales del } \\
\text { Rosario y San Bernardo }\end{array}$ & II & & 19506 & 100494 & 120000 \\
\hline 7 & 1977 & PNN/NNP Sanquianga & II & \multirow{3}{*}{$\begin{array}{l}\text { Pacifico continental/ } \\
\text { Continental Pacific }\end{array}$} & 80000 & 0 & 80000 \\
\hline 8 & 1984 & PNN/NNP Gorgona & II & & 1850 & 60125 & 61975 \\
\hline 9 & 1987 & PNN/NNP Utría & II & & 41106 & 13193 & 54300 \\
\hline 10 & 1995 & $\begin{array}{l}\text { PNN/NNP Old Providence- } \\
\text { McBean Lagoon }\end{array}$ & II & $\begin{array}{l}\text { Caribe insular/Insular } \\
\text { Caribbean }\end{array}$ & 89 & 1526 & 1615 \\
\hline 11 & 1995 & SFF Malpelo & $\mathrm{Ib}$ & $\begin{array}{l}\text { Pacifico insular/ } \\
\text { Insular Pacific }\end{array}$ & 350 & 2667558 & 2667908 \\
\hline
\end{tabular}




\begin{tabular}{|c|c|c|c|c|c|c|c|}
\hline $\mathbf{N} .^{\circ}$ & $\begin{array}{c}\text { Año de } \\
\text { creación/ } \\
\text { Creation } \\
\text { year }\end{array}$ & Nombre/Name & $\begin{array}{l}\text { Categoría } \\
\text { UICN/ } \\
\text { IUCN } \\
\text { Category }\end{array}$ & $\begin{array}{l}\text { Región/ } \\
\text { Region }\end{array}$ & $\begin{array}{c}\text { Área de cobertura } \\
\text { terrestre/Land } \\
\text { coverage área } \\
\text { (ha) }\end{array}$ & $\begin{array}{c}\text { Área de cobertura } \\
\text { marina/Marine } \\
\text { coverage area } \\
\text { (ha) }\end{array}$ & $\begin{array}{c}\text { Área de cobertura } \\
\text { total/Total coverage } \\
\text { area } \\
\text { (ha) }\end{array}$ \\
\hline 12 & 2002 & $\begin{array}{l}\text { PNN/NNP El Corchal } \\
\text { Mono Hernández }\end{array}$ & II & $\begin{array}{l}\text { Caribe continental/ } \\
\text { Continental Caribbean }\end{array}$ & 3850 & 0 & 3850 \\
\hline 13 & 2010 & $\begin{array}{l}\text { PNN/ NNP Uramba Bahía } \\
\text { Málaga }\end{array}$ & II & $\begin{array}{l}\text { Pacifico continental/ } \\
\text { Continental Pacific }\end{array}$ & 0 & 47094 & 47094 \\
\hline 14 & 2013 & $\begin{array}{l}\text { PNN/NNP Corales de } \\
\text { Profundidad }\end{array}$ & II & \multirow{3}{*}{$\begin{array}{c}\text { Caribe continental/ } \\
\text { Continental Caribbean }\end{array}$} & 0 & 142192 & 142192 \\
\hline 15 & 2013 & $\begin{array}{l}\text { SF Acandí, Playón y } \\
\text { Playona }\end{array}$ & $\mathrm{Ib}$ & & 0 & 26232 & 26232 \\
\hline 16 & 2014 & $\begin{array}{c}\text { PNN/NNP Bahía Portete - } \\
\text { Kaurrele }\end{array}$ & II & & 2692 & 11387 & 14080 \\
\hline 17 & 2017 & $\begin{array}{c}\text { DNMI/NDIM Yuruparí - } \\
\text { Malpelo }\end{array}$ & VI & $\begin{array}{l}\text { Pacifico insular/ } \\
\text { Insular Pacific }\end{array}$ & 0 & 2691981 & 2691981 \\
\hline 18 & 2017 & $\begin{array}{c}\text { DNMI/NDIM Cabo } \\
\text { Manglares, Bajo Mira y } \\
\text { Frontera }\end{array}$ & VI & $\begin{array}{l}\text { Pacifico continental/ } \\
\text { Continental Pacific }\end{array}$ & 10088 & 180193 & 190282 \\
\hline
\end{tabular}

Cinco de las AMP evaluadas no tienen cobertura marina (SFF Los Flamencos, PNN Sierra Nevada de Santa Marta, SFF Ciénaga Grande de Santa Marta, PNN El Corchal Mono Hernández y PNN Sanquianga), pero se tuvieron en cuenta en el análisis al contener ecosistemas costeros como playas, acantilados, estuarios, manglares, entre otros.

En la Figura 1 se observa que hasta 2010, cuando se declaran 13 AMP, la cobertura de área marina protegida correspondía a 1216414 ha, equivalente a 1,4\% de la cobertura marina total del país. Con la posterior declaración de cinco nuevas AMP y la ampliación del SFF Malpelo en el 2017 (Tabla 1), se alcanzó una cobertura de 5977804 ha, equivalente a $6,7 \%$ de la cobertura marina total actual del país. Este incremento de cobertura marina protegida, junto con las 17 AMP del ámbito regional (12 612213 ha), le permitieron a Colombia cumplir y sobrepasar la meta 11 Aichi del CDB, logrando $14 \%$ de la superficie marina en AMP (MADS y PNUD, 2019).

Para llevar a cabo el análisis de representatividad se utilizó una aplicación web geográfica denominada Sistema de Soporte de Decisiones del SAMP de Colombia (SSDSAMP) (http://gis.invemar.org.co/ssdsamp), teniendo como principal proveedor de información el Sistema de Información Ambiental Marino (SIAM) (https://siam. invemar.org.co) y el Registro Único Nacional de Áreas
Santa Marta, SFF Ciénaga Grande de Santa Marta, NNP El Corchal Mono Hernández, and NNP Sanquianga). Still, they are taken into account in the analysis as they contain coastal ecosystems such as beaches, cliffs, estuaries, and mangroves.

Figure 1 shows how until 2010, when 13 MPAs were designated, the marine protected area coverage corresponded to 1216414 ha, equivalent to $1.4 \%$ of the country's total marine coverage. With the subsequent designation of five new MPAs and the expansion of the SFF Malpelo in 2017 (Table 1) a coverage of 5977804 ha was achieved, equivalent to $6.7 \%$ of the country's current total marine coverage. This increase in protected marine coverage, together with the 17 MPAs at the sub-national level (12 $612213 \mathrm{ha}$ ), allowed Colombia to meet and exceed the 11 Aichi Target of the CBD, achieving $14 \%$ the marine area in MPAs (MADS and UNDP, 2019).

The tool used to make the analysis was a geographic web application called the Colombian SAMP Decision Support System (DSS-SAMP) (http:/gis. invemar.org.co/ssdsamp) having the Marine Environmental Information System (SIAM) (https://siam.invemar.org. $\mathrm{co} /$ ) and the National Single Registry of Protected Areas (RUNAP) (https://runap.parquesnacionales.gov.co/) as the primary information providers. It is supported by a heterogeneous technological environment with Linux 


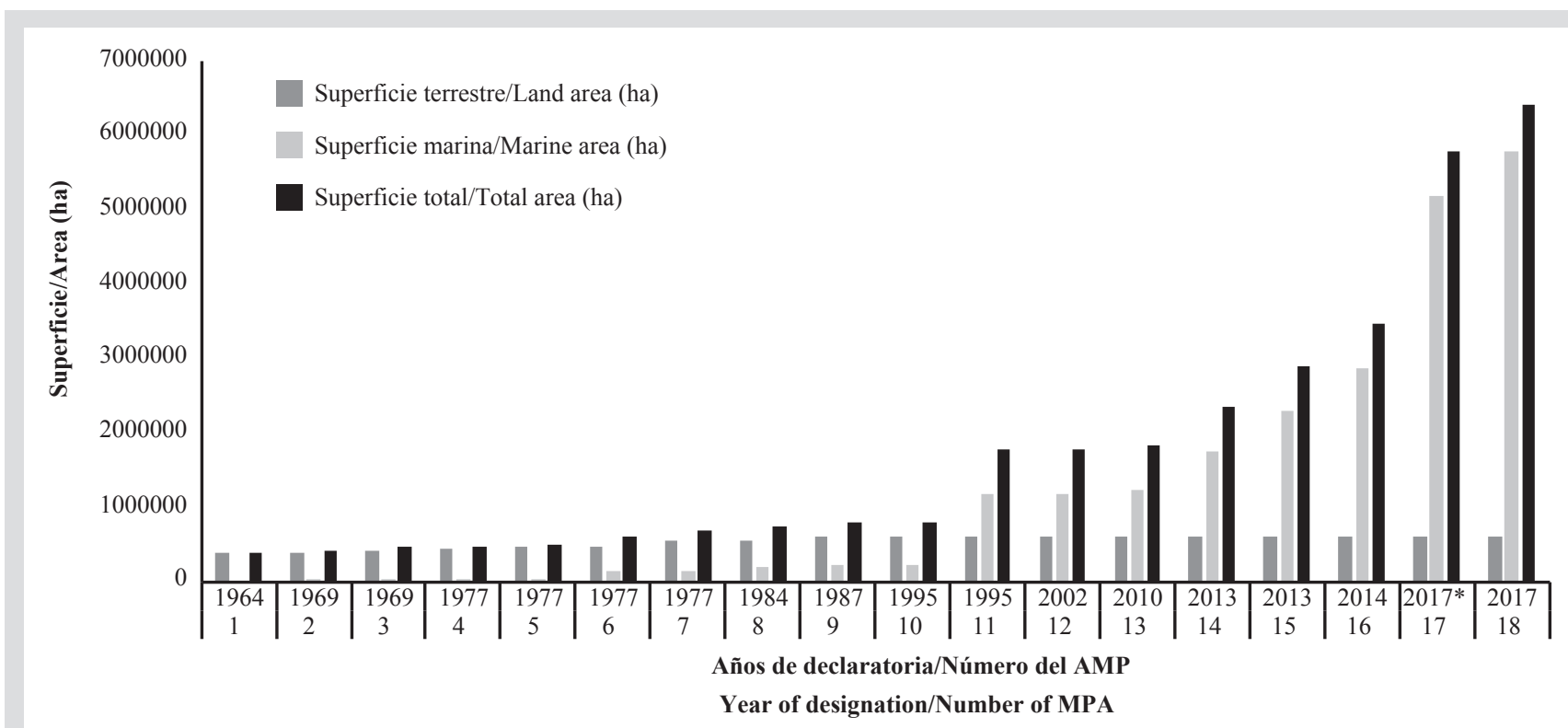

Figura 1. Línea de tiempo en la declaración de las 18 Áreas Marinas Protegidas administradas por Parques Nacionales Naturales de Colombia. Sumatoria de la superficie terrestre, marina y total de las áreas marinas protegidas. *Se incluye la ampliación en superficie del área marina del SFF Malpelo (1 709404 ha), aprobada en el 2017 (Resolución del MADS 1907 de 2017). El número de cada AMP corresponde a la Tabla 1.
Figure 1. Timeline in the designation of the 18 Marine Protected Areas managed by National Natural Parks of Colombia. Sum of the land, marine, and total surface of the areas. *Extending surface of the marine area of the SFF Malpelo (1 709404 ha), it was approved in 2017 (MADS Resolution 1907, 2017). The number of MPA corresponds to Table 1.
Protegidas (RUNAP) (https://runap.parquesnacionales. gov.co). El SSD-SAMP es soportado por un ambiente tecnológico heterogéneo con sistemas operativos Linux y Windows (Centos 6 y Windows server 2018R2), servidor de cartografía ArcGISServer (v. 10.3.1), lenguajes de programación Python (v. 2.7), Java (v. 1.7.0_21-b11), y Javascrip (v. Jquery 2.1.4 y ArcGIS API for Javascript 3.16), motor de base de datos Oracle (v. Oracle Database 11g Release 11.2.0.4.0 - 64bit Production) y Geodatabase (v. 10.3.1) (Bohórquez et al., 2010; Segura-Quintero, 2019). Este SSD permite evaluar la representatividad del SAMP, de manera jerárquica entre las AMP del ámbito de gestión nacional y regional. La herramienta registra cuánto de la superficie de cada ecosistema marino y costero se encuentra bajo protección en cada AMP, asumiendo la precisión de acuerdo con la escala en la que cada uno se encuentra representado cartográficamente (SeguraQuintero, 2019).

Para el análisis se seleccionaron 11 ecosistemas marinos y costeros para el Caribe y 11 para el Pacífico. La fuente de información cartográfica de cada ecosistema utilizada por el SSD-SAMP puede ser consultada directamente en el SIAM y se encuentra a escala de 1:5000 a 1:100000, a excepción de las geoformas del fondo marino que se encuentran a escala 1:500000. Las and Windows operating systems (Centos 6 and Windows Server 2018R2), ArcGISServer mapping server (v. 10.3.1), Python programming languages (v. 2.7), Java (v. 1.7.0_21b11), and Javascript (v. Jquery 2.1.4 and ArcGIS API for Javascript 3.16), Oracle Database Engine (v. Oracle Database 11g Release 11.2.0.4.0 - 64bit Production) and Geodatabase (v. 10.3.1) (Bohórquez et al., 2010; SeguraQuintero, 2019). This DSS makes it possible to evaluate the SAMP's representativeness hierarchically between the MPAs of the national and sub-national management. The tool records how much of each marine and coastal ecosystem's surface is under protection in each MPA, assuming precision according to the scale on which each one is mapped (Segura-Quintero, 2019).

For the analysis, 11 marine and coastal ecosystems were selected for the Caribbean and 11 for the Pacific. The source of cartographic information for the ecosystem used by DSS-SAMP can be consulted directly from SIAM and is at a scale of 1:5000 to 1:100000, except the seabed geoforms scale 1:500000. The representativeness ranges were used equivalent to those used in the 2010 analysis (Segura-Quintero et al., 2012), adjusting the names according to the last analysis performed for SINAP in the land component (SINAP, 2019). The ranges are expressed as a percentage of the extension or 
clases de representatividad utilizadas fueron equivalentes a las usadas en el análisis de 2010 (Segura-Quintero et al. 2012), ajustando los nombres de acuerdo con el último análisis realizado para el SINAP en el componente terrestre (SINAP, 2019). Las clases se expresan como un porcentaje de la extensión o cobertura del ecosistema dentro del SPNN, así: Sobrerepresentado o $\operatorname{Sr}(\geq 60 \%)$, Representatividad alta o Ra (30-59\%), Representatividad media o Rm (10-29 \%), Representatividad baja o Rb $(<10 \%)$ y $\operatorname{Sin}$ representatividad o $\operatorname{SinR}(0 \%)$.

En la Figura 2A se observa que en los últimos diez años el Caribe presentó un aumento en la representatividad de ecosistemas como manglares (1,5\%), pastos marinos $(2,3 \%)$, fondos sedimentarios $(2,9 \%)$, playas arenosas $(4,3 \%)$, playones salinos $(5,6 \%)$ y formaciones coralinas de profundidad $(64,7 \%)$. Se advierte como la representatividad de lagunas costeras y estuarios permanece estática, y continúan categorizados como $\mathrm{Rb}$, a pesar de ser considerados ecosistemas de sala cuna, críticos para el ciclo de vida de muchas especies de peces e invertebrados al proveerlos de hábitat, refugio y alimentación (Beck et al., 2001; Sheaves, 2009; Nagelkerken et al., 2015), además su función y valor es conferida por el mosaico de hábitats con los que interactúan (pastos marinos, manglares y corales) (Sheaves et al., 2015). Para el ecosistema de estuarios también se observa una $\mathrm{Rb}$ al incluir AMP de ámbito regional en el análisis de SINAP (SINAP, 2019). Se destaca la inclusión al SPNN de un nuevo ecosistema como son las formaciones coralinas de profundidad, al designarse una nueva AMP en el 2013 (PNN Corales de Profundidad), identificada por ejercicios de selección de prioridades de conservación (Alonso et al., 2007, 2008, 2010) y como un vacío de representatividad en el 2010 (Segura-Quintero et al., 2012).

Para el Pacífico colombiano aumentó la representatividad en los ecosistemas como los estuarios $(2,7 \%)$, fondos sedimentarios (3\%), manglares $(3,1 \%)$, planos intermareales de lodo $(3,2 \%)$, playas arenosas $(8 \%)$ y montañas submarinas $(8,5 \%)$ (Figura $2 \mathrm{~B})$. Se observa cómo en la última década no mejora la representatividad en el bosque mixto de guandal $(0,5 \%)$, considerado un ecosistema importante por la gran riqueza de especies vegetales que se encuentran en estrecha asociación con la franja de bosque de manglar en el Pacífico de Colombia (del Valle, 2000; Álvarez-Dávila et al., 2016); esta tendencia del bosque mixto de guandal también se observó en el análisis de SINAP que tuvo en cuenta las AMP del ámbito regional coverage of the ecosystem within the SPNN, as follows: Overrepresented or Or ( $\geq 60 \%)$, High representativeness or $\mathrm{Hr}$ (30-59\%), Medium representativeness or Mr (10$29 \%)$, Low representativeness or $\operatorname{Lr}(<10 \%)$ and No representativeness or $\mathrm{Nr}(0 \%)$.

In Figure $2 \mathrm{~A}$ it is observed how in the last ten years, the Caribbean presented an increase in the representativeness of ecosystems such as mangroves (1.5\%), seagrasses $(2.3 \%)$, sedimentary bottoms $(2.9 \%)$, sandy beaches $(4.3 \%)$, saline beaches $(5.6 \%)$ and deep-sea coral formations $(64.7 \%)$. However, the representativeness of coastal lagoons and estuaries remains static. They continue to be categorized as Lr, despite being considered nursery ecosystems, critical for the life cycle of many species of fish and invertebrates by providing them with habitat, shelter, and food (Beck et al., 2001; Sheaves, 2009; Nagelkerken et al., 2015), also their function and value is conferred by the mosaic of habitats with which they interact (seagrasses, mangroves, and corals) (Sheaves et al., 2015). An $\mathrm{Lr}$ is also observed for the estuarine ecosystem when including sub-national MPAs in the SINAP analysis (SINAP, 2019). The inclusion to the SPNN of a new ecosystem such as the deep-sea coral formations is highlighted when a new MPA was designated in 2013 (NNP Corales de Profundidad), identified by selection exercises of conservation priorities (Alonso et al., 2007, $2008,2010)$ and gap analysis for representativeness in 2010 (Segura-Quintero et al., 2012).

For the Colombian Pacific, the representativeness of ecosystems such as estuaries (2.7 \%), sedimentary bottoms (3\%), mangroves $(3.1 \%)$, intertidal mudflats (3.2\%), sandy beaches $(8 \%)$, and seamounts $(8.5 \%)$ increased (Figure 2B). It is observed that in the last decade, the representativeness in the mixed guandal forest has not improved $(0.5 \%)$, considered an essential ecosystem due to the great richness of plant species that are in close association with the mangrove forest strip in the Pacific of Colombia (del Valle, 2000; ÁlvarezDávila et al., 2016). This mixed guandal forest trend was also observed in the SINAP analysis that considered the sub-national MPAs (SINAP, 2019). The increase in the seamounts (Malpelo and Yuruparí ridges) as a conservation target or a substitute for biodiversity within the SAMP is highlighted (Codechocó et al., 2014; Alonso et al., 2015). Recent global evaluations show that although geoforms such as submarine mountains and canyons, escarpments and abyssal hills have high biodiversity values (Morato 
A)

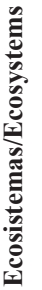

B)

2010

2020

Playas rocosas/Rocky beaches

Montañas submarinas/Sseamounts

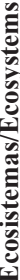

Planos intermareales de lodo/Intertidal mud flats

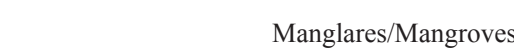

Manglares/Mangroves

Acantilado/Cliffs

Riscales/Rocky reef

Fondos sedimentarios/Sedimentary bottoms

Playas arenosas/Sandy beaches

Bosque mixto de guandal/Guandal mixed forest

$\mid 0$

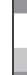

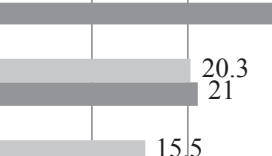

21
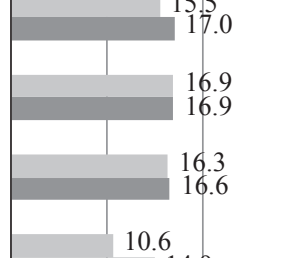

.
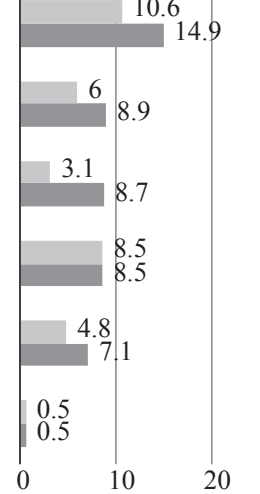

20

30

40

50

60

70

80

Representatividad/Representativeness (\%)

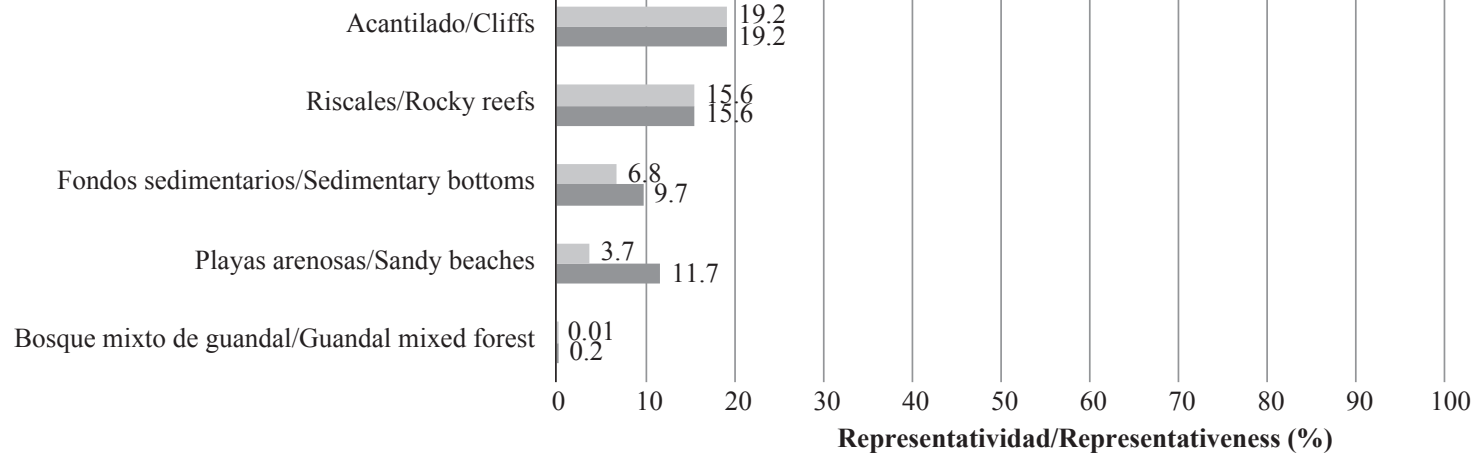

Figura 2. Cambios en la representatividad de los ecosistemas marinos y costeros en las áreas marinas protegidas administradas por Parques Nacionales Naturales de Colombia del año 2010 a 2020. A) Caribe colombiano. B) Pacífico colombiano. Clases de representatividad: sobrerrepresentado - $\mathrm{Sr}(\geq 60 \%)$, representatividad alta - $\mathrm{Ra}(30-59 \%)$, representatividad media $-\mathrm{Rm}(10-29 \%)$, representatividad baja $-\mathrm{Rb}$ $(<10 \%)$ y $\sin$ representatividad $-\operatorname{SinR}(0 \%)$.
Figure 2. Changes in the representativeness of marine and coastal ecosystems in marine protected areas managed by National Natural Parks of Colombia from 2010 to 2020. A) Colombian Caribbean. B) Colombian Pacific. Representativeness ranges: Overrepresented -Or ( $\geq 60 \%)$, High representativeness $-\mathrm{Hr}$ (30-59\%), Medium representativeness - $\mathrm{Mr}$ (10$29 \%)$, Low representativeness $-\operatorname{Lr}(<10 \%)$ and No representativeness $-\mathrm{Nr}(0 \%)$. 
(SINAP, 2019). Por otra parte, se destaca el aumento en la representatividad de las montañas submarinas (dorsales de Malpelo y Yuruparí) como un objeto de conservación o sustituto de biodiversidad dentro del SAMP (Codechocó et al., 2014; Alonso et al., 2015). Recientes evaluaciones globales demuestran que aunque geoformas como montes y cañones submarinos, escarpes y colinas abisales poseen altos valores de biodiversidad (Morato et al., 2010; Kvile et al., 2014; Durden et al., 2015; Huang et al., 2018), no se encuentran bien representados en sistemas de AMP nacionales (Fischer et al., 2019).

En general se observa a 2020 una mejora en las clases de representatividad de ecosistemas en el SPNN (Tabla 2), al cambiar el único ecosistema SinR (corales de profundidad) a $\mathrm{Sr}$, disminuir el número de ecosistemas en $\mathrm{Rb}$ y aumentar el número a Rm. Lo anterior se traduce en un incremento de representatividad de los ecosistemas, donde la sumatoria de Rm, Ra y Sr pasó de 59,1\% en 2010 a $68,2 \%$ en 2020. Sin embargo, estos resultados no pretenden dejar la responsabilidad del cumplimiento de las metas de representatividad de los ecosistemas marinos y costeros del país exclusivamente al SPNN, sino por el contrario, permiten identificar cuánto es el aporte al SAMP y cómo complementan las metas con las AMP del ámbito regional, las cuales no fueron objeto de este estudio. et al., 2010; Kvile et al., 2014; Durden et al., 2015; Huang et al., 2018), they are not well represented in national MPA systems (Fischer et al., 2019).

By 2020, an improvement is observed in the representativeness ranges of ecosystems in the SPNN (Table 2). The only $\mathrm{Nr}$ ecosystem (deep-sea corals) change to Or, decrease the number of ecosystems in Lr, and increased the number to Mr. The representativeness increased when the sum of $\mathrm{Mr}, \mathrm{Hr}$, and $\mathrm{Or}$ went from $59.1 \%$ in 2010 to $68.2 \%$ in 2020 . However, these results do not pretend to fulfill the representativeness's target exclusively to the SPNN, but rather to identify how much the contribution to SAMP and complement the goals with sub-national MPAs, which were not the subject of this study.

The most significant conservation effort in MPAs of the SPNN and general of the SAMP has been concentrated on the continental shelf $(\leq 200 \mathrm{~m})$, which is only equivalent to $6 \%$ of the jurisdictional waters of Colombia (Exclusive Economic Zone) (Invemar, 2020), but is in these environments where the greater scientific knowledge of biodiversity has been gathered (Costello et al., 2010; Miloslavich et al., 2011). Therefore, Colombia must incorporate the high biodiversity values
Tabla 2. Clases de representatividad de ecosistemas marinos y costeros en el Sistema de Parques Nacionales Naturales de Colombia y su variación entre 2010 y 2020.
Table 2. Representativeness ranges of marine and coastal ecosystems in the System of National Natural Parks and their variation between 2010 and 2020 in Colombia.

\begin{tabular}{|c|c|c|c|c|c|}
\hline \multicolumn{2}{|l|}{ Representatividad/Representativeness } & \multicolumn{4}{|c|}{ Ecosistemas/Ecosystems } \\
\hline \multirow{2}{*}{ Clases/Ranges } & \multirow{2}{*}{$\%$} & \multicolumn{2}{|c|}{$\mathbf{N} .^{\circ}$} & \multicolumn{2}{|c|}{$\%$} \\
\hline & & 2010 & 2020 & 2010 & 2020 \\
\hline Sin representatividad $(\operatorname{SinR}) /$ No representativeness $(\mathrm{Nr})$ & 0 & 1 & 0 & 4.5 & 0 \\
\hline Representatividad baja $(\mathrm{Rb}) /$ Low representativeness $(\mathrm{Lr})$ & $<10$ & 8 & 7 & 36.4 & 31.8 \\
\hline Representatividad media (Rm)/Medium representativeness (Mr) & $10-29$ & 9 & 10 & 40.9 & 45.5 \\
\hline Representatividad alta (Ra)/High representativeness (Hr) & $30-59$ & 3 & 3 & 13.6 & 13.6 \\
\hline Sobrerepresentado (Sr)/Overrepresented (Or) & $\geq 60 \%$ & 1 & 2 & 4.5 & 9.1 \\
\hline TOTAL & & 22 & 22 & 100 & 100 \\
\hline
\end{tabular}

El mayor esfuerzo de conservación en AMP del SPNN y en general del Subsistema se ha concentrado sobre la plataforma continental $(\leq 200 \mathrm{~m})$, que sólo equivale a $6 \%$ de las aguas jurisdiccionales del país associated with deep benthic habitats (Harris and Baker, 2012), without creating large MPAs with low biodiversity and little threat, as has happened in other regions of the world to meet commitments to the CBD (Williams 
(Zona Económica Exclusiva) (Invemar, 2020), lo cual va en concordancia con el mayor conocimiento científico de biodiversidad que existe en estos ambientes (Costello et al., 2010; Miloslavich et al., 2011). Por lo anterior, es importante que Colombia incorpore los altos valores de biodiversidad que se encuentran asociados a hábitats bentónicos profundos (Harris y Baker, 2012), sin crear grandes AMP con baja biodiversidad y poco amenazadas, como ha sucedido en otras regiones del mundo, para cumplir con los compromisos con el CDB (Williams et al., 2009; Devillers et al., 2015). El reto de mejorar esta representatividad debería recaer sobre el MADS como autoridad ambiental nacional, quien podría delegar su administración a PNNC por su experiencia con áreas remotas u oceánicas. De acuerdo con Fisher et al. (2019), la inclusión de hábitats bentónicos profundos en AMP ha comenzado a reconocerse globalmente, al encontrar que, de 230 países evaluados, 74 incluyeron cañones submarinos y 38 incluyeron montes submarinos. Dado el crecimiento de las actividades productivas mar afuera como la extracción de minerales, pesca de arrastre, explotación de petróleo y gas (Davies et al., 2007; Ramírez-Llodra et al., 2011; Cordes et al., 2016), entre otras, Colombia debe explorar la aplicación de nuevas categorías de manejo como Reserva Natural y Área Natural Única propuestas por la UICN (Categorías I y III, respectivamente; Dudley, 2008). Estas categorías se han designado en la última década en países como EE. UU., Canadá y Francia para este tipo de ambientes profundos (Fernández-Arcaya et al., 2017); un caso reciente fue la designación en EE. UU. del Northeast Canyons and Seamounts Marine National Monument (Categoría III-UICN) (Costello, 2019; Auster et al., 2020). Un próximo desafío para avanzar en la planificación para la conservación marina del país es incluir en los análisis de representatividad el nivel de organización biológica de especies e incorporar como atributo del SAMP el criterio de conectividad (funcional y estructural) (Balbar y Metaxas, 2019), tomando como áreas núcleo las AMP del SPNN; sin embargo es importante conceptualizar aún más sobre este aspecto (SINAP, 2019).

En el proceso de construcción del marco global para la biodiversidad posterior a 2020, el CBD propone aumentar $30 \%$ de la superficie terrestre y marina en áreas protegidas y otras medidas de conservación eficaces basadas en áreas para el 2030 (CBD, 2018). Esta nueva meta global parece ser una ruta de trabajo correcta (O'Leary et al., 2016; Woodley et al., 2019), luego del reciente et al., 2009; Devillers et al., 2015). The challenge of improving this representativeness should fall on MADS as a National Environmental Authority, which could delegate its administration to PNNC for its experience with remote or oceanic areas. According to Fisher et al. (2019), the inclusion of deep benthic habitats in MPAs has begun to be recognized globally, finding that of 230 countries evaluated, 74 included submarine canyons, and 38 included seamounts. Given the growth of offshore productive activities such as mineral extraction, trawling, oil, and gas exploitation (Davies et al., 2007; Ramírez-Llodra et al., 2011; Cordes et al., 2016), among others, Colombia should explore the application of new management categories such as Natural Reserve and Unique Natural Area proposed by the IUCN (Categories I and III, respectively, Dudley, 2008). Those categories have been designated in the last decade in countries such as the USA, Canada, and France for this type of deep habitats environment (Fernández-Arcaya et al., 2017). A recent case was the designation in USA of the Northeast Canyons and Seamounts Marine National Monument (Category III-IUCN) (Costello, 2019; Auster et al., 2020). A next challenge to advance in planning for the country's marine conservation is to include in the representativeness analyzes the level of biological organization of species and to incorporate as an attribute of the SAMP the connectivity criteria (functional and structural) (Balbar and Metaxas, 2019), taking as core the MPAs of the SPNN. However, it is crucial to conceptualize even more about this aspect (SINAP, 2019).

In the process of building the global framework for biodiversity post-2020, the CBD proposes to increase to $30 \%$ the protected land and sea surface by 2030 , either by protected areas or other effective area-based conservation measures (CBD, 2018). This new global goal seems to be a correct work path (O'Leary et al., 2016; Woodley et al., 2019), after the recent diagnosis of the global assessment report on biodiversity and ecosystem services (IPBES, 2019). It was identified that the most important direct drivers of biodiversity loss are habitat fragmentation and loss (changes in the use of land and sea) and direct exploitation, with the overexploitation of fishery resources being the most important in marine systems. Moreover, the assessment reported that $66 \%$ of the ocean surface experiences an increasing cumulative impact, and more than $85 \%$ of the wetlands have disappeared (IPBES, 2019). Additionally, a recent multisector financial analysis 
diagnóstico de la evaluación global sobre la biodiversidad y los servicios de los ecosistemas (IPBES, 2019), donde se identificó que los impulsores directos más importantes de la pérdida de biodiversidad son la fragmentación y pérdida del hábitat (cambios en el uso de la tierra y el mar) y la explotación directa, siendo la sobreexplotación de recursos pesqueros más importante en los sistemas marinos. Por otro lado, la evaluación registró que $66 \%$ de la superficie del océano experimenta un impacto acumulativo creciente y más de $85 \%$ de los humedales han desaparecido (IPBES, 2019). Adicionalmente, un reciente análisis financiero multisectorial (incluyendo agricultura, silvicultura, pesca y conservación) estimó una mayor producción (ingresos) al expandir las áreas protegidas a $30 \%$ en el planeta, pudiendo generarse, entre \$ 64 y \$ 454 billones de dólares por año para 2050, incluso luego de los posibles efectos económicos que está generando la COVID-19 (Waldron et al., 2020).

Es importante para Colombia, con una cobertura de $50 \%$ de territorio marino (Invemar, 2019), aprovechar los diferentes escenarios internacionales frente a la futura conservación de los océanos, como son: 1) La construcción del nuevo marco pos-2020 del CDB, en donde el país debe apoyar la meta de $30 \%$ a 2030, garantizando de forma eficiente un balance entre cobertura y representatividad del SAMP; 2) Colombia por su experiencia puede nutrir el debate y las definiciones que se desarrollen en el proyecto de "Acuerdo Marco de la Convención de las Naciones Unidas sobre el Derecho del Mar, relativo a la conservación y el uso sostenible de la diversidad biológica marina en Áreas Fuera de la Jurisdicción Nacional" (UN, 2019), donde uno de los principales puntos es el manejo de herramientas de gestión de áreas, incluidas las áreas marinas protegidas, y 3) La proclamación del Decenio de las Ciencias Oceánicas para el Desarrollo Sostenible de las Naciones Unidas (2021-2030) por parte de la Asamblea General de las Naciones Unidas (UN, 2020), al reconocer la ciencia como un prerrequisito para gestionar el océano de manera sostenible, y un pilar fundamental para la implementación de todos los Objetivos de Desarrollo Sostenible (ODS) de la Agenda 2030 y específicamente el ODS 14 Vida Submarina.

Basado en lo anterior, se puede concluir que: 1) la contribución de las AMP administradas por PNNC a la representatividad de ecosistemas marinos y costeros del SAMP mejoró a 2020, en algunos ecosistemas estratégicos como pastos marinos, manglares, playas arenosas $\mathrm{y}$ (including agriculture, forestry, fishing, and conservation) estimated a higher production (income) by expanding protected areas to $30 \%$ on the planet, being able to generate between $\$ 64$ to $\$ 454$ billion dollars per year by 2050 , even after the possible economic effects that it is generating to recovery from the effects of COVID-19 (Waldron et al., 2020).

It is essential for Colombia, with her coverage of $50 \%$ of marine territory (Invemar, 2019), to take advantage of the different international scenarios, facing the future conservation of the oceans, such as: 1) The construction of the new post-2020 framework of the CBD, where Colombia should support the target of $30 \%$ to 2030, but efficiently guaranteeing a balance between coverage and representativeness of the SAMP; 2) Colombia, through its experience, can support the debate and the definitions that are developed in the draft "Framework Agreement of the United Nations Convention on the Law of the Sea, relative to the conservation and sustainable use of marine biological diversity in Areas Beyond National Jurisdiction" (ABNJ) (UN, 2019), where one of the main points is the management of area management tools, including MPAs; and 3) The proclamation of the United Nations Decade of Ocean Sciences for Sustainable Development (2021-2030), by the United Nations General Assembly (UN, 2020), recognizing science as a pre-requisite for sustainable managing of the ocean, and a fundamental pillar for the implementation of the Sustainable Development Goals (SDGs) of the 2030 Agenda and mainly the SDG 14 Life Below Water.

Based on the above, it can be concluded that: 1) the contribution of the MPAs managed by PNNC to the representativeness of marine and coastal ecosystems of the SAMP improved by 2020, in some strategic ecosystems such as seagrasses, mangroves, sandy beaches, and the inclusion of a new ecosystem such as deep-sea corals, specifically in the Caribbean. The opposite was for mixed guandal forest in the Pacific and coastal lagoons and estuaries in the Caribbean. However, meeting the goals does not lie exclusively with the SPNN since there are 17 sub-national MPAs. This analysis only allows us to understand the 18 MPAs of the national management scope. 2) The need to increase research and knowledge of deep benthic habitats is noted to include them in conservation priorities and the analysis of gaps in SAMP representativeness. 3) Colombia should take advantage of international dialogue scenarios to contribute and commit 
la inclusión de un nuevo ecosistema como los corales profundos, específicamente en el Caribe. Caso contrario para ecosistemas como bosque mixto de guandal en el Pacífico y lagunas costeras y estuarios en el Caribe. No obstante, la responsabilidad del cumplimiento de las metas no es exclusivamente del SPNN, ya que existen 17 AMP del ámbito de gestión regional; este análisis solo permite comprender la contribución de las 18 áreas del ámbito de gestión nacional. 2) Se advierte la necesidad de incrementar la investigación y conocimiento de los hábitats bentónicos profundos para incluirlos dentro de ejercicios de prioridades de conservación y en los análisis de vacíos de representatividad del SAMP. 3) Colombia debe aprovechar los escenarios de diálogo internacional para contribuir y comprometerse con metas ambiciosas de conservación del CBD (30 \% al 2030) y apoyar la declaratoria de posibles AMP en áreas fuera de la jurisdicción nacional, basado en su experiencia con la declaratoria y manejo de AMP oceánicas (SFF Malpelo y PNN Corales de Profundidad). to ambitious CBD conservation goals (30\% by 2030) and support the declaration of possible MPAs in ABNJ based on their experience with the designation and management of oceanic MPAs (SFF Malpelo and NNP Deep-sea Corals).

\section{ACKNOWLEDGMENTS}

The authors would like to thank the Institute of Marine and Coastal Research "José Benito Vives de Andréis" (Invemar) for its institutional support, especially Julián Pizarro and Felipe Valencia from the Laboratory of Information Services (Labsis). Finally, the anonymous reviewer and the editor in charge who contributed with their comments and observations to the improvement of this work. Contribution 1289 of Invemar.

\section{AGRADECIMIENTOS}

Los autores agradecen al Instituto de Investigaciones Marinas y Costeras "José Benito Vives de Andréis" (Invemar) por su apoyo institucional, en especial a Julián Pizarro y a Felipe Valencia del Laboratorio de Servicios de Información (Labsis). Por último, al evaluador anónimo y al editor encargado quienes contribuyeron con sus comentarios y observaciones a la mejora de este trabajo. Contribución 1289 del Invemar.

\section{BIBLIOGRAFÍA/LITERATURE CITED}

Airamé, S., J.E. Dugan, K.D. Lafferty, H. Leslie, D.A. McArdle, and R.R. Warner. 2003. Applying ecological criteria to marine reserve design: A case study from the California Channel Islands. Ecol. Appl., 13: 170-184. https://doi.org/10.1890/1051-0761

Alonso, D., L. Ramírez, J.M. Díaz, C. Segura-Quintero, P. Castillo, and A. Chatwin. 2007. Coastal and marine conservation priorities in Colombia. 3039. In: Chatwin, A. (Ed.). Priorities for coastal and marine conservation in South America. The Nature Conservancy-TNC, Arlington. 63 p.

Alonso, D., C. Segura-Quintero, P. Castillo-Torres, and J. Gerhantz-Muro. 2008. Marine protected areas network design: conservation strategy for the Colombian northern continental Caribbean. Bol. Invest. Mar. Cost., 37: 129-156.

Alonso, D., C. Segura-Quintero, P. Torres, D. Rozo-Garzón, J. Espriella, J. Bolaños y A. Lopez. 2010. Áreas significativas para la biodiversidad. 393419. En: Invemar. (Ed.). Biodiversidad del margen continental del Caribe colombiano. Invemar, Santa Marta. 457 p.

Alonso, D., H. Barbosa, M. Duque, I. Gil, M. Morales, S. Navarrete, M. Nieto, A. Ramírez, G. Sanclemente y J. Vásquez. 2015. Conceptualización del Subsistema de Áreas Marinas Protegidas en Colombia. Ser. Publ. Gener. Invemar, (88), 80 p.

Álvarez-Dávila, E., G. Jaramillo-Giraldo, C. Cogollo-Rivera, H. Martínez-Higuera, E. Rojas, and F. Fernández-Méndez. 2016. Structure and diversity of the three plant associations in the San Juan River delta, Chocó, Colombia. Árvore, 40: 833-843. doi.org/10.1590/0100-67622016000500007

Auster, P.J., B.C. Hodge, M.P. McKee, and S.D. Kraus. 2020. A scientific basis for designation of the northeast canyons and seamounts marine national monument. Front. Mar. Sci., 7: 566. doi.org/10.3389/fmars.2020.00566 
Balbar, A.C. and A. Metaxas. 2019. The current application of ecological connectivity in the design of marine protected areas. Glob. Ecol. Conserv., 17: e00569. doi.org/10.1016/j.gecco.2019.e00569

Barr, L.M., R.L. Pressey, R.A. Fuller, D.B. Segan, E. McDonald-Madden, and H.P. Possingham. 2011. A new way to measure the world's protected area coverage. PLoS One, 6: 9. doi.org/10.1371/journal.pone.0024707

Beck, M.W., K.L. Heck, K.W. Able, D.L. Childers, D.B. Eggleston, B.M. Gillanders, B. Halpern, C.G. Hays, K. Hoshino, T.J. Minello, R.J. Orth, P.F. Sheridan, and M.P. Weinstein. 2001. The identification, conservation, and management of estuarine and marine nurseries for fish and invertebrates. Bioscience, 51: 633-641. doi.org/10.1641/0006-3568(2001)051[0633:TICAMO]2.0.CO;2

Bohórquez, J.C., C. Segura-Quintero y P. Lozano. 2010. Diseño del sistema de soporte a la toma de decisiones para el subsistema de Áreas Marinas Protegidas. Informe técnico final. Invemar, Santa Marta. 13 p.

CDB. 2004. Decision COP 7/12. https://www.cbd.int/decisions/cop/7/28. 14/07/2020.

CDB. 2010. The Strategic Plan for Biodiversity 2011-2020 and the Aichi Biodiversity Targets. https://www.cbd.int/decisions/cop/10/2. 19/07/2020.

CDB. 2018. Decision adopted by the conference of the parties to the Convention on Biological Diversity 14/8. Protected areas and other effective areabased conservation measures. https://www.cbd.int/doc/decisions/cop-14/cop-14-dec-08-en.pdf. 25/07/2020.

Codechocó, Carder, Corponariño, CRC, CVC, IIAP, Invemar, PNN y WWF. 2014. Prioridades de conservación costeras y oceánicas del SIRAP Pacífico. Informe técnico final. WWF, Cali. 146 p.

Cordes, E.E., D.O.B. Jones, T.A. Schlacher, D.J. Amon, A.F. Bernardino, S. Brooke, R. Carney, D.M. DeLeo, K.M. Dunlop, E.G. Escobar-Briones, A.R. Gates, L. Génio, J. Gobin, L.A. Henry, S. Herrera, S. Hoyt, M. Joye, S. Kark, N.C. Mestre, A. Metaxas, S. Pfeifer, K. Sink, A.K. Sweetman, and U. Witte. 2016. Environmental impacts of the deep-water oil and gas industry: a review to guide management strategies. Front. Environ. Sci., 4: 58. https://doi.org/10.3389/fenvs.2016.00058

Costello, M.J., M. Coll, R. Danovaro, P. Halpin, H. Ojaveer, and P. Miloslavich. 2010. A census of marine biodiversity knowledge, resources, and future challenges. PLoS One, 5:8. doi.org/10.1371/journal.pone.0012110

Costello, T. 2019. Are marine national monuments “situated on lands owned or controlled by the Government of the United States?” Oc. Coast. Law J., 24:2. https://digitalcommons.mainelaw.maine.edu/oclj/vol24/iss $2 / 5$

Davies, A.J., J.M. Roberts, and J. Hall-Spencer. 2007. Preserving deep-sea natural heritage: Emerging issues in offshore conservation and management. Biol. Conserv., 138: 299-312. doi.org/10.1016/j.biocon.2007.05.011

Decreto 2811. 1974. Diario oficial de la Republica de Colombia. Presidencia de la República de Colombia. https://www.minambiente.gov.co/images/ GestionIntegraldelRecursoHidrico/pdf/normativa/Decreto_2811_de_1974.pdf. 12/07/2020.

Del Valle, J.I. 2000. Consideraciones estructurales de los bosques de guandal del Pacifico sur colombiano. Rev. Fac. Nal. Agr. Medellín, 53: 1011-1042.

Devillers, R., R.L. Pressey, A. Grech, J.N. Kittinger, G.J. Edgar, T. Ward, and R. Watson. 2015. Reinventing residual reserves in the sea: are we favouring ease of establishment over need for protection? Aquat. Conserv. Mar. Freshw. Ecosyst., 25: 480-504. doi.org/10.1002/aqc.2445

Dudley, N. (Ed). 2008. Guidelines for applying protected area management categories. IUCN, Gland, Switzerland. 143 p.

Dudley, B.Y. and J. Parish. 2006. Closing the gap. Creating ecologically representative protected area systems: a guide to conducting the gap assessments of protected area systems for the Convention on Biological Diversity. CBD Tech. Ser., (24). 108 p. doi.org/10.1111/j.1469-7610.2010.02316.x

Durden, J.M., B.J. Bett, D.O.B. Jones, V.A.I. Huvenne, and H.A. Ruhl. 2015. Abyssal hills-hidden source of increased habitat heterogeneity, benthic megafaunal biomass and diversity in the deep sea. Prog. Oceanogr., 137: 209-218. doi.org/10.1016/j.pocean.2015.06.006

Fernández-Arcaya, U., E. Ramírez-Llodra, J. Aguzzi, A.L. Allcock, J.S. Davies, A. Dissanayake, P. Harris, K. Howell, V.A.I. Huvenne, M. MacmillanLawler, J. Martín, L. Menot, M. Nizinski, P. Puig, A.A. Rowden, F. Sánchez, and I.M.J. den Beld. 2017. Ecological role of submarine canyons and need for canyon conservation: a review. Front. Mar. Sci., 4: 5. doi.org/10.3389/fmars.2017.00005

Fischer, A., D. Bhakta, M. Macmillan-Lawler, and P. Harris. 2019. Existing global marine protected area network is not representative or comprehensive measured against seafloor geomorphic features and benthic habitats. Oc. Coast. Manag., 167: 176-187. doi.org/10.1016/j.ocecoaman.2018.10.001

Gaines, S.D., C. White, M.H. Carr, and S.R. Palumbi. 2010. Designing marine reserve networks for both conservation and fisheries management. Proc. Natl. Acad. Sci., 107(43): 18286-18293. doi.org/10.1073/pnas.0906473107

Gell, F.R. and C.M. Roberts. 2003. Benefits beyond boundaries: the fishery effects of marine reserves. Trends Ecol. Evol., 18: 448-455. doi.org/10.1016/ S0169-5347(03)00189-7 
Harris, P.T. and E.K. Baker. 2012. Geohab atlas of seafloor geomorphic features and benthic habitats: synthesis and lessons learned. 871-890. In: Harris, P. and E. Baker (Eds.). Seafloor geomorphology as benthic habitat. Elsevier, CIUDAD???. 936 p. doi.org/10.1016/B978-0-12-385140-6.00064-5

Huang, Z., T.A. Schlacher, S. Nichol, A. Williams, F. Althaus, and R. Kloser. 2018. A conceptual surrogacy framework to evaluate the habitat potential of submarine canyons. Prog. Oceanogr., 169: 199-213. doi.org/10.1016/j.pocean.2017.11.007

Invemar. 2020. Informe del estado de los ambientes y recursos marinos y costeros en Colombia 2019. Ser. Publ. Periód. Invemar, (3), 183 p.

IPBES, 2019. Summary for policymakers of the global assessment report on biodiversity and ecosystem services of the Intergovernmental SciencePolicy Platform on Biodiversity and Ecosystem Services. doi.org/https://doi.org/10.5281/zenodo.3553579

Kvile, K.O., G.H. Taranto, T.J. Pitcher, and T. Morato. 2014. A global assessment of seamount ecosystems knowledge using an ecosystem evaluation framework. Biol. Conserv., 173: 108-120. doi.org/10.1016/j.biocon.2013.10.002

MADS-PNUD. 2019. Sexto informe de Colombia ante el Convenio de Diversidad Biológica. https://www.cbd.int/doc/nr/nr-06/co-nr-06-es.pdf. $18 / 07 / 2020$

Margules, C.R. and R.L. Pressey. 2000. Systematic conservation planning. Nature, 405: 243-253. doi.org/10.1038/35012251

Miloslavich, P., E. Klein, J.M. Díaz, C.E. Hernández, G. Bigatti, L. Campos, F. Artigas, J. Castillo, P.E. Penchaszadeh, P.E. Neill, A. Carranza, M.V. Retana, J.M. Díaz de Astarloa, M. Lewis, P. Yorio, M.L. Piriz, D. Rodríguez, Y. Yoneshigue-Valentin, L. Gamboa, and A. Martín. 2011. Marine biodiversity in the Atlantic and Pacific Coasts of South America: knowledge and gaps. PLoS One, 6: 1. doi.org/10.1371/journal.pone.0014631

Morato, T., S.D. Hoyle, V. Allain, and S. J. Nicol. 2010. Seamounts are hotspots of pelagic biodiversity in the open ocean. Proc. Natl. Acad. Sci., 107(21): 9707-9711. doi.org/10.1073/pnas.0910290107

Nagelkerken, I., M. Sheaves, R. Baker, and R.M. Connolly. 2015. The seascape nursery: a novel spatial approach to identify and manage nurseries for coastal marine fauna. Fish Fish., 16: 362-371. doi.org/10.1111/faf.12057

O’Leary, B.C., M. Winther-Janson, J.M. Bainbridge, J. Aitken, J.P. Hawkins, and C.M. Roberts. 2016. Effective coverage targets for ocean protection. Conserv. Lett., 9(6): 398-404. doi.org/10.1111/conl.12247

Ramírez-Llodra, E., P.A. Tyler, M.C. Baker, O.A. Bergstad, M.R. Clark, E. Escobar, L.A. Levin, L. Menot, A.A. Rowden, C.R. Smith, and C.L. Van Dover. 2011. Man and the last great wilderness: human impact on the deep sea. PLoS One 6: e22588. https://doi.org/10.1371/journal.pone.0022588

Sala, E., O. Aburto-Oropeza, G. Paredes, I. Parra, J.C. Barrera, and P.K. Dayton. 2002. A general model for designing networks of marine reserves. Science, 298: 1991-1993. https://doi.org/10.1126/science.1075284

Segura-Quintero, C. 2019. Geoservicio web para el análisis de la representatividad ecosistémica: aporte al diseño y gestión del subsistema de Áreas Marinas Protegidas de Colombia. Univ. Salzburg, Bogotá. 103 p.

Segura-Quintero, C., D. Alonso y L. Ramírez. 2012. Análisis de vacíos de representatividad en las Áreas Marinas Protegidas del Sistema de Parques Nacionales Naturales de Colombia. Bol. Invest. Mar. Cost., 41: 299-322.

Sheaves, M. 2009. Consequences of ecological connectivity: the coastal ecosystem mosaic. Mar. Ecol. Prog. Ser., 391: 107-115. doi.org/10.3354/ meps 08121

Sheaves, M., R. Baker, I. Nagelkerken, and R.M. Connolly. 2015. True value of estuarine and coastal nurseries for fish: incorporating complexity and dynamics. Estuaries Coast., 38: 401-414. doi.org/10.1007/s12237-014-9846-x

SINAP, 2019. Hacia una política para el Sistema Nacional de Áreas Protegidas de Colombia 2021-2030. Informe técnico, PNN, WWF, GEF y BID, Bogotá D.C. 84 p. https://www.parquesnacionales.gov.co/portal/es/sistema-nacional-de-areas-protegidas-sinap/representatividad-y-prioridades-deconservacion/13/10/2020

Stevens, T. 2002. Rigor and representativeness in marine protected area design. Coast. Manag., 30(3): 237-248. doi.org/10.1080/08920750290042183

UN. 2019. Proyecto de texto de un acuerdo en el marco de la Convención de las Naciones Unidas sobre el derecho del mar relativo a la conservación y el uso sostenible de la diversidad biológica marina de las zonas situadas fuera de la jurisdicción nacional. https://undocs.org/es/A/CONF.232/2019/6 $20 / 07 / 2020$

UN. 2020. United Nations Decade of Ocean Science for Sustainable Development (2021-2030). Zero Draft- Implementation Plan, United Nations, New York. 48 p.

Waldron, A., A. Vanessa, A. James, A. Arnell, G. Asner, S. Atkinson, et al. 2020. Protecting $30 \%$ of the planet for nature: costs, benefits and economic implications. Working paper analyzing the economic implications of the proposed $30 \%$ target for areal protection in the draft post-2020 Global Biodiversity Framework. Campaign for Nature. https://www.conservation.cam.ac.uk/files/waldron_report_30_by_30_publish.pdf. 24/07/2020. 
Williams, A., N.J Bax, R.J. Kloser, F. Althaus, B. Barker, and G. Keith. 2009. Australia's deep-water reserve network: implications of false homogeneity for classifying abiotic surrogates of biodiversity. ICES J. Mar. Sci., 66(1): 214-224. doi.org/10.1093/icesjms/fsn189

Woodley, S., H. Locke, D. Laffoley, K. MacKinnon, T. Sandwith, and J. Smart. 2019. A review of evidence for area-based conservation targets for the post-2020 global biodiversity framework. PARKS, 25(2): 31-46. doi.org/10.2305/iucn.ch.2019.parks-25-2sw2.en

RECIBIDO/RECEIVED: 26/07/2020

ACEPTADO/ACCEPTED: 08/11/2020 